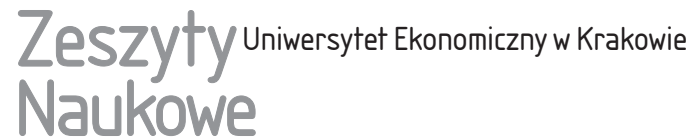

\section{Wpływ restrykcyjności regulacji nadzorczych na stabilność banków spółdzielczych w krajach Unii Europejskiej}

\section{Streszczenie}

Celem przedstawionych w artykule badań była identyfikacja determinant stabilności finansowej banków spółdzielczych w Unii Europejskiej w latach 2008-2015 ze szczególnym uwzględnieniem wpływu restrykcyjności działań regulacyjnych na stabilność finansową banków spółdzielczych w krajach UE. W artykule dokonano przeglądu badań determinant stabilności banków spółdzielczych oraz przedstawiono wyniki wywiadów pogłębionych dotyczących czynników wpływających na stabilność tych podmiotów w ocenie kadry zarządzającej oraz przedstawicieli sieci bezpieczeństwa finansowego. W badaniach panelowych obejmujących 1753 banki spółdzielcze w krajach UE wykazano, że w krajach o wyższym poziomie restrykcyjności regulacji nadzorczych obserwuje się wyższe wartości wskaźników adekwatności kapitałowej banków spółdzielczych. Jednocześnie potwierdzono negatywny wpływ intensywności regulacji bankowych w kraju na stabilność banków spółdzielczych mierzonych indeksem MLPS. Wykorzystanie miernika opartego na szerszej definicji stabilności finansowej wskazuje zatem, że długookresowe zwiększanie restrykcyjności regulacji przez podmioty sieci bezpieczeństwa finansowego pomimo zwiększania bazy kapitałowej banków doprowadza do pogorszenia wielokryterialnej oceny stabilności finansowej.

Słowa kluczowe: banki spółdzielcze, stabilność finansowa, regulacje bankowe, kraje UE. Klasyfikacja JEL: G01, G21, G28. 


\section{Wprowadzenie}

W następstwie globalnego kryzysu finansowego 2007-2009 obserwowany jest znaczny wzrost zainteresowania problematyką stabilności finansowej na całym świecie oraz zmiana jej paradygmatu (Szambelańczyk 2010, s. 39-65). W warunkach kryzysu finansowego zapewnienie stabilności finansowej banków nabiera szczególnego znaczenia. System finansowy jest bowiem nie tylko usługodawcą i dostarczycielem kapitału, ale także stabilizuje podstawowe funkcje w gospodarce (Alińska 2012, s. 23).

Praktyka ponoszenia kosztów ewentualnej upadłości instytucji finansowej w głównej mierze przez podatników, a nie przez jej właścicieli, sprawia, że stabilność systemu finansowego, w szczególności zaś bankowego, zaczęła być rozpatrywana w kategoriach dobra publicznego. Uwypukliło to z jednej strony potrzebę implementowania i egzekwowania mechanizmów ograniczających pokusę podejmowania nadmiernie ryzykownej działalności przez zarządy pośredników finansowych, jakimi są banki (tzw. normy ostrożnościowe), a z drugiej - znaczenie narzędzi odpowiednio wcześnie sygnalizujących pogarszającą się sytuację banków w obszarze stabilności finansowej, mogącą prowadzić do upadłości. Właściwy pomiar stabilności finansowej umożliwia podjęcie działań prewencyjnych, co pozwala zredukować konsekwencje zarówno dla budżetu państwa w przypadku udzielania pomocy publicznej, jak i dla gospodarki w przypadku upadłości banków (Gradoń 2014, s. 254-266). Doświadczenia pokryzysowe zrodziły potrzebę nowego podejścia do szacowania ryzyka i stabilności banków, w szczególności wypracowania nowych technik i metod analizy zagrożeń oraz wrażliwości banków na ryzyko (Miklaszewska 2011b, s. 125).

W literaturze przedmiotu jako jedną z przyczyn globalnego kryzysu finansowego 2007-2009 wskazuje się problemy w obszarze regulacji i nadzoru nad rynkiem bankowym (Dam 2010, s. 581; Merrouche i Nier 2010). Jako działania zaradcze wskazano wprowadzenie wielu istotnych zmian w sferze regulacyjnej sektora bankowego (Maciejewski 2014, s. 102-104). W latach 2011-2016 w obszarze rynku finansowego Unii Europejskiej podjęto prace nad 56 regulacjami, przy czym 37 zostało już wdrożonych ${ }^{1}$.

Jednocześnie zwraca się uwagę, że tworzeniu pokryzysowych regulacji towarzyszył niekiedy pośpiech wynikający z obaw przed powrotem kryzysu finansowego i niska jakość tych regulacji, rozumiana m.in. jako nieprecyzyjność, niezrozumiałość czy wadliwość definiowanych pojęć (Masiukiewicz i Morawska 2015, s. 69). Nowe regulacje makro- i mikroostrożnościowe są w znacznej mierze wyni-

${ }^{1}$ K. Pietraszkiewicz, prezentacja przedstawiona w ramach spotkania koordynatorów programu Nowoczesne Zarządzanie Biznesem, Warszawa, 21 czerwca 2017 r. 
kiem negatywnej weryfikacji dotychczasowych struktur nadzorczych w krajach wysoko rozwiniętych. Kraje Europy Środkowo-Wschodniej natomiast nie miały potrzeby tak istotnej modyfikacji struktur nadzorczych i regulacyjnych jak kraje wysoko rozwinięte, ale musiały przystosować się do nowych rozwiązań (Miklaszewska 2011a, s. 55-56).

W literaturze podkreśla się, że zasada proporcjonalności w dotychczasowym procesie legislacyjnym była mocno marginalizowana (Kasiewicz i Kurkliński 2014, s. 234). Oznacza to jednakowe traktowanie bardzo dużych banków z liczną siecią powiązań transgranicznych (o znaczeniu systemowym) i niewielkich lokalnych instytucji kredytowych. Banki spółdzielcze działające w Unii Europejskiej są przykładem małych podmiotów depozytowo-kredytowych, których obowiązki regulacyjne i sprawozdawcze są niemal takie same jak dużych banków o globalnym charakterze. Lokalny charakter działalności banków spółdzielczych wynika z ograniczonego obszaru działania, zakresu oferty produktowej, troski o lokalną społeczność, więzi między klientami a bankiem oraz misji (Nowacka i Szewczyk-Jarocka 2015, s. 185-192).

W literaturze przedmiotu podkreśla się, że kryzys finansowy miał mniejsze znaczenie dla stabilności banków spółdzielczych niż komercyjnych (Księżopolski 2013, s. 81). W powszechnej opinii przedstawicieli sektora banków spółdzielczych za jedną z najważniejszych przyczyn pogorszenia się w okresie pokryzysowym stabilności tej grupy podmiotów uważa się zmiany regulacyjne, w tym zwiększenie obciążeń sprawozdawczych oraz konieczność modyfikacji modelu biznesowego.

Nie ma konsensusu w zakresie definiowania stabilności finansowej. Zróżnicowanie koncepcyjne dotyczy przede wszystkim tego, czy definicja dotyczy stabilności finansowej konkretnej instytucji finansowej (ujęcie mikroekonomiczne), rynku finansowego (w szczególności rynku bankowego), czy całego systemu finansowego (Rogowski i Mesjasz 2012, s. 23-24). Po analizie literatury oraz stanowiska przedstawicieli sieci bezpieczeństwa finansowego i kadry zarządzającej banków spółdzielczych uznano, że w dalszej części artykułu stabilność finansowa banku spółdzielczego definiowana będzie w perspektywie mikroekonomicznej, zgodnie z koncepcją, którą zaproponowali I.R. Diaconu i D.C. Oanea (2015, s. 488-495). W koncepcji tej stabilność finansowa banku jest postrzegana dwojako - jako zdolność banku do efektywnej alokacji zasobów w czasie i przestrzeni oraz do właściwej oceny i zarządzania ryzykiem finansowym.

Celem przedstawionych w niniejszym artykule badań jest identyfikacja determinant stabilności banków spółdzielczych w Unii Europejskiej w latach 2008-2015 ze szczególnym uwzględnieniem wpływu restrykcyjności działań regulacyjnych na stabilność finansową banków spółdzielczych w krajach UE. 


\section{Przegląd badań na temat determinant stabilności banków spółdzielczych}

Banki spółdzielcze różnią się znacznie od banków komercyjnych, dlatego różne są często również czynniki wpływające na ich stabilność finansową (Fiordelisi i Mare 2014). G. Ferri (2012) jako istotną przyczynę wyższej oceny stabilności banków spółdzielczych w stosunku do ich komercyjnych konkurentów wskazał przede wszystkim rozbudowaną bazę depozytową oraz lepszy monitoring ekspozycji kredytowych, wynikający z bliskiej współpracy i znajomości klientów. Przeprowadzone w 2015 r. badania dotyczące rumuńskiego sektora banków spółdzielczych w latach 2008-2013 wykazały m.in. istotny statystycznie wpływ wartości wskaźnika $L / D$ (kredyty/depozyty sektora niefinansowego) oraz brak wpływu dynamiki wzrostu gospodarczego na stabilność finansową tych podmiotów.

Badania oparte na kwartalnych danych o bankach spółdzielczych i systemie bankowym przeprowadził S. Kozak (2010). Jako zmienne charakteryzujące stabilność banków spółdzielczych wykorzystał współczynnik wypłacalności $C A R$, tj. relację kapitałów własnych do aktywów ważonych ryzykiem, oraz wskaźnik kredytów zagrożonych NPL. Zgodnie z wynikami badań współczynnik wypłacalności banków spółdzielczych wzrastał w okresach obniżającej się dynamiki PKB. Taka zależność może oznaczać, że banki spółdzielcze w okresie globalnego kryzysu miały w stosunku do banków komercyjnych przewagę w postaci bardzo szerokiego dostępu do stosunkowo tanich źródeł finansowania, tj. depozytów gospodarstw domowych. Pozwalało im to generować zyski netto przeznaczane na podwyższenie kapitałów własnych. Drugim źródłem tej zależności jest fakt inwestowania przez banki spółdzielcze istotnej części aktywów w lokaty w bankach zrzeszających, obarczone znacznie niższym poziomem ryzyka kredytowego niż inwestycje w kredyty dla sektora niefinansowego. Wniosek ten jest zbieżny z wynikami badań, które przeprowadzili H. Hesse i M. Čihák (2007), oraz wnioskami zawartymi w raporcie World Council of Credit Unions (Cooperative...2009), z których wynika, że banki spółdzielcze są bardziej stabilne niż banki komercyjne, szczególnie w okresie kryzysów finansowych. Z kolei stabilność banków oceniana za pomocą $N P L$, zgodnie z wynikami badań, była w okresie kryzysu pozytywnie skorelowana z dynamiką przyrostu PKB. Oznacza to, że w okresach wzrostu dynamiki przyrostu PKB banki zwiększają wartość nowo udzielanych kredytów i tym samym obniżają udział kredytów zagrożonych w banku. W stosunku do wszystkich zmiennych objaśnianych wpływ aktywności na rynku akcji i wartości głównych indeksów giełdowych okazał się minimalny, choć w większości przypadków istotny statystycznie (Kozak 2010, s. 260-262).

Ł. Kozłowski w 2015 r. przeprowadził także analizy determinant stabilności banków spółdzielczych (mierzonej przede wszystkim wartością wskaźnika NPL) 
działających w Polsce w latach 2007-2013 (Kozłowski 2015, s. 180-199). W zakres analiz włączono zmienne opisujące funkcjonowanie banków spółdzielczych w kontekście kosztów działania (w relacji do sumy bilansowej), tworzonych odpisów aktualizacyjnych z tytułu utraty wartości, odnotowywanej marży odsetkowej netto, rentowności (mierzonej ROA i OROA), dynamiki aktywów (w ujęciu urealnionym), wielkości banku (logarytm aktywów), struktury jego aktywów i pasywów (udział kapitału własnego w pasywach oraz należności z tytułu kredytów w aktywach), a także modelu biznesowego (udział wyniku z tytułu prowizji w wyniku działalności bankowej). Ponadto w modelu wykorzystano zmienne makroekonomiczne: poziom wynagrodzeń, aktywność gospodarczą ludności, stopę bezrobocia oraz gęstość zaludnienia na terenach funkcjonowania każdego z analizowanych banków spółdzielczych. Włączono także charakterystyki konkurencji na rynku lokalnym (w promieniu 2,5 km) - mediany liczby konkurentów (banków komercyjnych, SKOK-ów oraz banków spółdzielczych), z jakimi mierzą się jego poszczególne placówki. Jednym z najistotniejszych wniosków płynących z analiz dotyczy negatywnego wpływu obecności SKOK-ów i budowanej przez nie konkurencji na stabilność banków spółdzielczych. W obliczu konkurencji ze strony kas, prowadzących stosunkowo liberalną politykę pożyczkową skutkującą wysokim udziałem należności przeterminowanych w portfelu pożyczkowym, banki spółdzielcze rozluźniały politykę kredytową i podejmowały większe ryzyko (Kozłowski 2015, s. 180-199).

Na podstawie wywiadów pogłębionych (o charakterze poglądowym) przeprowadzonych w 2017 r. należy stwierdzić, że opinia dotycząca determinant stabilności finansowej wskazywanych przez prezesów banków spółdzielczych oraz przedstawicieli podmiotów sieci bezpieczeństwa finansowego w Polsce jest zróżnicowana. Jednym z najczęściej wskazywanych czynników oddziałujących na poziom stabilności finansowej tych podmiotów jest poziom rynkowych stóp procentowych (tabela 1).

Tabela 1. Determinanty stabilności finansowej banków spółdzielczych wskazywane przez kadrę zarządzającą banków spółdzielczych oraz przedstawicieli sieci bezpieczeństwa finansowego w Polsce (na podstawie wywiadów pogłębionych)

\begin{tabular}{|c|c|c|}
\hline $\begin{array}{c}\text { Oznaczenie } \\
\text { banku }\end{array}$ & Czynniki makroekonomiczne & Czynniki mikroekonomiczne \\
\hline BS Krasnystaw & $\begin{array}{l}\text { Czynniki w zakresie poziomu stóp } \\
\text { procentowych, tempa wzrostu polskiej } \\
\text { gospodarki, kształtowania się wskaź- } \\
\text { nika poziomu usług i cen konsumpcyj- } \\
\text { nych, sytuacji na rynku pracy, pozycji } \\
\text { finansowej gospodarstw domowych } \\
\text { oraz kondycji sektora przedsiębiorstw }\end{array}$ & $\begin{array}{l}\text { Poziom kapitałów własnych najwyż- } \\
\text { szej jakości CET1, poziom depozytów } \\
\text { stabilnych oraz aktywów wysoko } \\
\text { płynnych, poziom ryzyka kredyto- } \\
\text { wego, w tym przede wszystkim jakość } \\
\text { należności i zobowiązań pozabilanso- } \\
\text { wych, a także efektywność działania, }\end{array}$ \\
\hline
\end{tabular}


cd. tabeli 1

\begin{tabular}{|c|c|c|}
\hline $\begin{array}{c}\text { Oznaczenie } \\
\text { banku }\end{array}$ & Czynniki makroekonomiczne & Czynniki mikroekonomiczne \\
\hline & $\begin{array}{l}\text { niefinansowych. Nie bez wpływu } \\
\text { pozostają: kursy wymiany walut, } \\
\text { czynniki polityczno-prawne związane } \\
\text { z otoczeniem regulacyjnym, czynniki } \\
\text { społeczne związane z demografią } \\
\text { oraz zakres terytorialny prowadzonej } \\
\text { działalności }\end{array}$ & $\begin{array}{l}\text { w tym zyskowność i efektywność } \\
\text { kosztowa oraz jakość zarządzania. } \\
\text { Istotne wśród czynników bezpośred- } \\
\text { niego oddziaływania są też efektyw- } \\
\text { ność i rodzaje stosowanych mechani- } \\
\text { zmów kontrolujących ryzyko }\end{array}$ \\
\hline BS Grudusk & $\begin{array}{l}\text { Podstawowe stopy procentowe, } \\
\text { podatki, inflacja }\end{array}$ & $\begin{array}{l}\text { Zapotrzebowanie na akcję kredytową } \\
\text { i jakość portfela kredytowego }\end{array}$ \\
\hline BS Starogard & $\begin{array}{l}\text { Poziom rynkowych stóp procen- } \\
\text { towych; polityka pieniężna NBP } \\
\text { w zakresie stóp procentowych }\end{array}$ & $\begin{array}{l}\text { Poziom depozytów w relacji do } \\
\text { kredytów; kondycja finansowa dużych } \\
\text { kredytobiorców }\end{array}$ \\
\hline $\begin{array}{l}\text { Śląski BS } \\
\text { „Silesia” } \\
\text { w Katowicach }\end{array}$ & $\begin{array}{l}\text { Stopy procentowe, stabilność gospo- } \\
\text { darcza branży dominującej w regio- } \\
\text { nie działania; stabilność regulacji } \\
\text { zewnętrznych }\end{array}$ & $\begin{array}{l}\text { Polityka kapitałowa, umiarkowany } \\
\text { rozwój skoncentrowany na terenie } \\
\text { Śląska i sposób zarządzania bankiem }\end{array}$ \\
\hline $\begin{array}{l}\text { Wojciech } \\
\text { Kwaśniak } \\
\text { KNF/NBP }\end{array}$ & $\begin{array}{l}\text { Fundamentalne znaczenie ma poziom } \\
\text { stóp procentowych oraz zasady obcią- } \\
\text { żeń podatkowych (głównie w zakresie } \\
\text { uznawania odpisów na utratę wartości } \\
\text { jako kosztu uzyskania przychodu do } \\
\text { celów podatkowych). Istotne znaczenie } \\
\text { mają koszty regulacyjne }\end{array}$ & $\begin{array}{l}\text { Czynniki jakościowe związane } \\
\text { z jakością zarządzania bankiem oraz } \\
\text { dostępem banku do kapitału, płynno- } \\
\text { ści oraz technologii }\end{array}$ \\
\hline $\begin{array}{l}\text { Jan Szambe- } \\
\text { lańczyk } \\
\text { BFG }\end{array}$ & $\begin{array}{l}\text { Poziom bezrobocia na terenie działal- } \\
\text { ności banku, poziom stóp procento- } \\
\text { wych, tempo zmian PKB, obciążenie } \\
\text { kosztami działalności BFG na rzecz } \\
\text { gwarantowania depozytów i działalno- } \\
\text { ści resolution }\end{array}$ & $\begin{array}{l}\text { Jakość działalności kredytowej } \\
\text { (ryzyko kredytowe), ekonomika banku } \\
\text { (efektywność działalności), brak } \\
\text { możliwości rekapitalizacji w przy- } \\
\text { padku powstania strat (adekwatność } \\
\text { kapitałowa). W dłuższej perspektywie } \\
\text { wszystkie one są pochodną kompeten- } \\
\text { cji kadr banku }\end{array}$ \\
\hline
\end{tabular}

Źródło: opracowanie własne na podstawie wywiadów pogłębionych przeprowadzonych w $2017 \mathrm{r}$. z kadrą zarządzającą wybranych banków spółdzielczych oraz z przedstawicielami sieci bezpieczeństwa finansowego w Polsce.

Brak jednoznacznej oceny w zakresie istotności oraz kierunku oddziaływania poszczególnych zmiennych na stabilność finansową banków spółdzielczych stanowi jedną z istotnych przesłanek analizy tego problemu w dalszej części pracy. 


\section{Charakterystyka badań}

Badania panelowe nad stabilnością banków spółdzielczych w krajach Unii Europejskiej omówione w artykule dotyczą lat 2008-2015 i prowadzone były na podstawie danych pozyskanych z bazy Bankscope obejmującej 1753 banki². Analizy przeprowadzono zarówno w całej grupie banków, jak i w podziale na banki działające w dwóch typach krajów: grupa 1 - o dużym znaczeniu banków spółdzielczych jako kredytodawców dla sektora niefinansowego (ponad 10\% udziału w należnościach z tytułu kredytów dla sektora bankowego), 1582 podmioty, oraz grupa 2 - o mniejszym znaczeniu banków spółdzielczych w finansowaniu rynku niefinansowego (do $10 \%$ udziału w należnościach z tytułu kredytów całego sektora bankowego), 171 podmiotów. Do pierwszej grupy zaliczono banki spółdzielcze działające we Francji, Włoszech, Austrii, Finlandii, na Cyprze, w Holandii, Danii, Luksemburgu i Niemczech. Banki spółdzielcze działające w pozostałych krajach zostały przyporządkowane do drugiej grupy (por. rys. 1). Z uwagi na braki w danych oraz występowanie obserwacji nietypowych ostateczna liczba banków włączonych do analizy w przypadku poszczególnych modeli jest mniejsza, określona każdorazowo liczbą obserwacji.

Do przeprowadzenia testów statystycznych zdecydowano się zastosować dynamiczne modele panelowe. Wybór metody badawczej wynikał z faktu, że zebrane dane mają charakter danych panelowych, co oznacza możliwość obserwacji zmian w dwóch przekrojach jednocześnie, tj. w przekroju jednostek i czasu (Baltagi 2013). Podstawową zaletą tego typu danych jest to, że ich wykorzystanie w konstrukcji i estymacji modeli ekonometrycznych ułatwia weryfikację hipotez, zwiększa liczbę stopni swobody i redukuje problem współliniowości danych, a także ogranicza lub eliminuje obciążenie estymatorów (Dańska-Borsiak 2011, s. 19-20).

Modele zostały wyestymowane z wykorzystaniem uogólnionej metody momentów w wersji GMM-SYS. Wśród zalet tej metody należy wskazać brak założeń o ścisłej egzogeniczności regresorów, dzięki czemu można uwzględnić opóźnione wartości zmiennej zależnej, co nie jest możliwe w przypadku statycznych modeli panelowych (z efektami ustalonymi oraz z efektami losowymi indywidualnymi) (Kozłowski 2015, s. 2015). Estymator GMM-SYS daje w podobnych przypadkach bardziej wiarygodne i precyzyjne wyniki (Baltagi 2013).

W celach diagnostycznych wykorzystano test Sargana dla metody dwukrokowej oraz testy autokorelacji Arellano-Bonda dla pierwszych różnic: $A R(1)$ oraz

${ }^{2}$ W bazie Bankscope dostępne są dane jedynie ok. 30\% banków spółdzielczych działających w Unii Europejskiej, co należy uwzględnić przy ostatecznej interpretacji wyników. W szczególności brakuje danych dla banków działających w Polsce, co utrudnia prowadzenie analiz porównawczych. 
$A R(2)$, których wyniki pozwoliły na przeprowadzenie prawidłowego wnioskowania statystycznego.

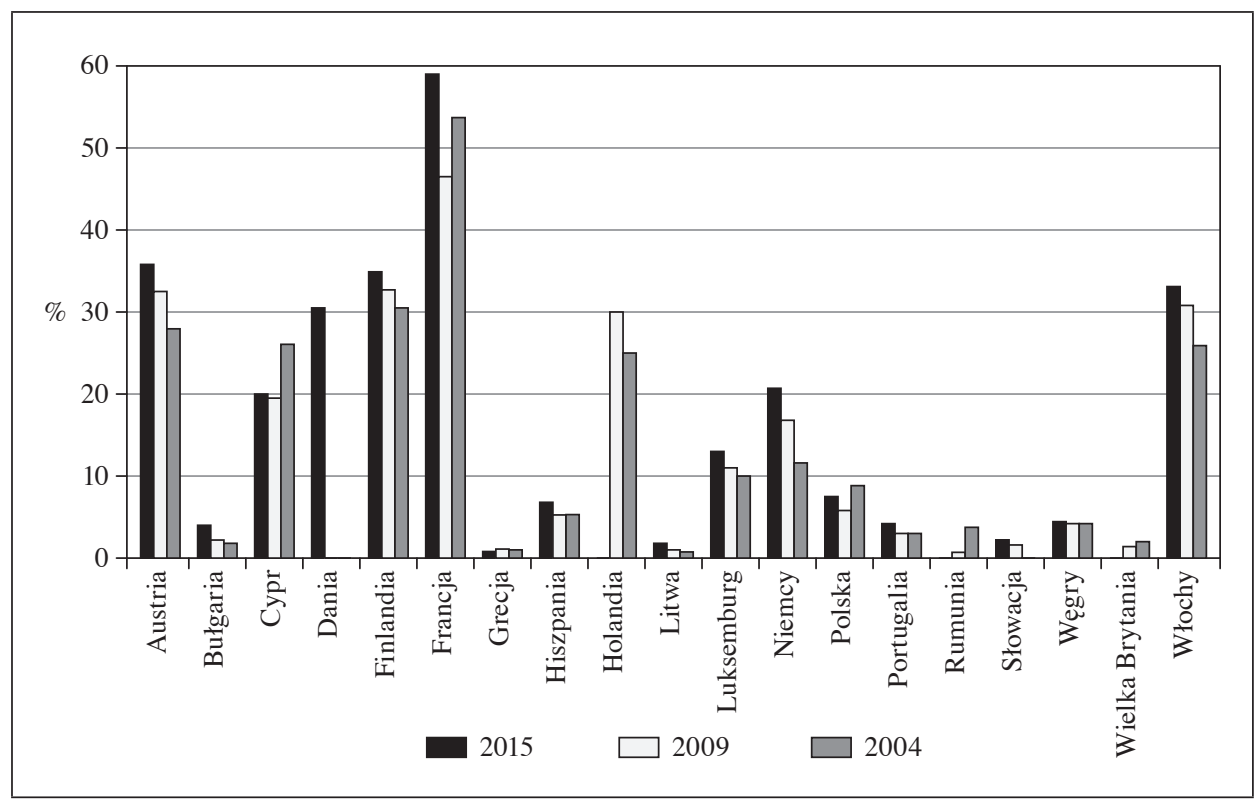

Rys. 1. Siła rynkowa banków spółdzielczych (mierzona udziałem w portfelu kredytów sektora bankowego udzielonych sektorowi niefinansowemu) w wybranych krajach Unii Europejskiej w latach 2004, 2009 i 2015

Źródło: opracowanie własne na podstawie danych EACB (http://www.eacb.coop/en/cooperative-banks/key-figures.html, data dostępu: 22.02.2017).

Ostateczny kształt estymowanych dynamicznych modeli regresji dany jest równaniem:

$S T A B_{i t}=a_{0}+a_{1} \cdot S T A B_{i t-1}+a_{2} \cdot Z M \cdot M A K R O_{i t}+a_{2} \cdot Z M \cdot M I K R O_{i t}+Z M \cdot R E G U L_{i t}+v_{i t}$, gdzie:

$S T A B$ - jedna z miar stabilności finansowej wykorzystana w badaniach, $Z M . M A K R O_{i t}$ - wektor wartości zmiennych makroekonomicznych kraju i sektora, wpływających na stabilność banku spółdzielczego w okresie $t$,

$Z M . M I K R O_{i t}$ - wektor zmiennych kontrolnych charakteryzujących specyfikę działania konkretnego banku spółdzielczego,

ZM.REGUL $L_{i t}$ - wektor zmiennych opisujących intensywność regulacji w sektorach bankowych poszczególnych krajów,

$v_{i t}$ - czynnik losowy dla banku $i$ w okresie $t$. 
Zmienne do modelu zostały dobrane na podstawie analiz literatury przedmiotu, wywiadów pogłębionych oraz metod statystycznych. Charakterystykę zmiennych wykorzystanych w badaniach przedstawiono w tabeli 2 .

Tabela 2. Charakterystyka zmiennych wykorzystanych w badaniach panelowych stabilności banków spółdzielczych w krajach Unii Europejskiej w latach 2006-2015

\begin{tabular}{|c|c|c|}
\hline Zmienna & Opis & Źródło danych \\
\hline \multicolumn{3}{|c|}{ Zmienne objaśniane $(S T A B)$} \\
\hline$T C R$ & $\begin{array}{l}\text { Łączny współczynnik kapitałowy } \\
\text { (total capital ratio) - miara stabilności } \\
\text { oparta na wypłacalności banku w sze- } \\
\text { rokim ujęciu }\end{array}$ & \multirow[t]{2}{*}{ Bankscope } \\
\hline$T 1 R$ & $\begin{array}{l}\text { Współczynnik kapitału wysokiej } \\
\text { jakości (tier } 1 \text { ratio) - miara stabil- } \\
\text { ności oparta na wypłacalności banku } \\
\text { w wąskim ujęciu }\end{array}$ & \\
\hline Z-score & $\begin{array}{l}\text { Miara odległości od bankructwa - } \\
\text { miara stabilności oparta na poziomie } \\
\text { dźwigni i stabilności wyników działa- } \\
\text { nia banku }\end{array}$ & \multirow[t]{2}{*}{$\begin{array}{l}\text { Obliczenia własne na podstawie } \\
\text { danych z Bankscope }\end{array}$} \\
\hline MLP score & $\begin{array}{l}\text { Multi level performance score - miara } \\
\text { stabilności oparta na pięciu wskaźni- } \\
\text { kach bezpieczeństwa i rentowności, } \\
\text { autorska koncepcja E. Miklaszewskiej } \\
\text { i K. Kila (2016) }\end{array}$ & \\
\hline \multicolumn{3}{|c|}{ Zmienne objaśniające - charakterystyki makroekonomiczne } \\
\hline$K R \_P K B$ & $\begin{array}{l}\text { Relacja kredytów dla sektora niefi- } \\
\text { nansowego do PKB - miara rozwoju } \\
\text { rynku bankowego w poszczególnych } \\
\text { krajach }\end{array}$ & $\begin{array}{l}\text { Bank Światowy (http://data.worldbank. } \\
\text { org/indicator/FS.AST.DOMS.GD.ZS, } \\
\text { data dostępu: 15.02.2017) }\end{array}$ \\
\hline$C P I$ & $\begin{array}{l}\text { Zharmonizowany indeks cen kon- } \\
\text { sumenckich }(H I C P) \text { - miara inflacji } \\
\text { stosowana w krajach UE }\end{array}$ & $\begin{array}{l}\text { Eurostat (http://ec.europa.eu/eurostat/ } \\
\text { web/hicp/data/database, data dostępu: } \\
\text { 17.02.2017) }\end{array}$ \\
\hline$H H I$ & $\begin{array}{l}\text { Herfindahl-Hirschman index - miara } \\
\text { koncentracji sektora bankowego }\end{array}$ & EBC (consolidated banking data) \\
\hline$P K B$ & $\begin{array}{l}\text { Dynamika PKB w ujęciu średniorocz- } \\
\text { nym w kraju - miara tempa wzrostu } \\
\text { gospodarczego }\end{array}$ & $\begin{array}{l}\text { Eurostat (http://ec.europa.eu/eurostat/ } \\
\text { web/gdp/data/database, data dostępu: } \\
\text { 17.02.2017) }\end{array}$ \\
\hline$S P$ & $\begin{array}{l}\text { Jednomiesięczna stopa procentowa } \\
\text { rynku międzybankowego - miara } \\
\text { kosztu finansowania rynku między- } \\
\text { bankowego }\end{array}$ & $\begin{array}{l}\text { Eurostat (http://ec.europa.eu/eurostat/ } \\
\text { web/gdp/data/database, data dostępu: } \\
\text { 17.02.2017) }\end{array}$ \\
\hline
\end{tabular}


cd. tabeli 2

\begin{tabular}{|c|c|c|}
\hline Zmienna & Opis & Źródło danych \\
\hline \multicolumn{3}{|c|}{ Zmienne objaśniające - charakterystyki mikroekonomiczne } \\
\hline$L_{-} A K$ & $\begin{array}{l}\text { Logarytm wartości aktywów banku - } \\
\text { miara wielkości banku }\end{array}$ & $\begin{array}{l}\text { Obliczenia własne na podstawie } \\
\text { danych z Bankscope }\end{array}$ \\
\hline NIM & $\begin{array}{l}\text { Marża odsetkowa netto - miara efek- } \\
\text { tywności działania banku }\end{array}$ & \multirow[t]{6}{*}{ Bankscope } \\
\hline$R O E$ & $\begin{array}{l}\text { Przeciętna stopa zwrotu z kapitałów } \\
\text { własnych - miara rentowności }\end{array}$ & \\
\hline$C_{-} I$ & $\begin{array}{l}\text { Relacja kosztów do przychodów - } \\
\text { miara efektywności kosztowej }\end{array}$ & \\
\hline$A P \_D K$ & $\begin{array}{l}\text { Relacja aktywów płynnych do depo- } \\
\text { zytów krótkoterminowych - miara } \\
\text { płynności banku }\end{array}$ & \\
\hline$N P L$ & $\begin{array}{l}\text { Udział kredytów z utratą wartości } \\
\text { w portfelu kredytowym banku - miara } \\
\text { ryzyka kredytowego banku }\end{array}$ & \\
\hline$K_{-} A$ & $\begin{array}{l}\text { Udział kredytów w aktywach - miara } \\
\text { poziomu zaangażowania kredytowego } \\
\text { banku }\end{array}$ & \\
\hline WO_WNO & $\begin{array}{l}\text { Relacja wyniku odsetkowego netto do } \\
\text { wyniku nieodsetkowego - charaktery- } \\
\text { styka modelu biznesowego banku }\end{array}$ & \multirow[t]{2}{*}{$\begin{array}{l}\text { Obliczenia własne na podstawie } \\
\text { danych z Bankscope }\end{array}$} \\
\hline$D E P \_W Z$ & $\begin{array}{l}\text { Dynamika wzrostu depozytów - miara } \\
\text { zagrożenia paniką bankową (tzw. run } \\
\text { na bank) }\end{array}$ & \\
\hline \multicolumn{3}{|c|}{ Zmienne objaśniające - charakterystyki regulacji } \\
\hline$R E S T R \_R E G$ & $\begin{array}{l}\text { Indeks restrykcyjności regulacji } \\
\text { skonstruowany na podstawie badań } \\
\text { ankietowych Banku Światowego Bank } \\
\text { Regulation and Supervision Survey } \\
\text { (BRSS) }\end{array}$ & K. Sum (2015, s. 207-236) \\
\hline$R E G_{-} G L O B$ & $\begin{array}{l}\text { Indeks globalnych zmian regulacyj- } \\
\text { nych - roczna liczba zmian obliczona } \\
\text { na podstawie danych kwartalnych }\end{array}$ & $\begin{array}{l}\text { Banking Compliance Index-Regula- } \\
\text { tory Changes (https://cdn2.hubspot. } \\
\text { net/hubfs/40143/BCI_Report_- } \\
\text { Q1_2017_.pdf?t=1495061834808, data } \\
\text { dostępu: 17.02.2017) }\end{array}$ \\
\hline
\end{tabular}

Źródło: opracowanie własne.

Analizowane banki różnią się istotnie pod względem wielkości, modelu działalności oraz rentowności i stabilności.

Do analizy regulacji sektora bankowego wykorzystano m.in. wyniki badań ankietowych BRSS przeprowadzonych przez Bank Światowy w ramach czterech 
edycji - w latach 2001, 2003, 2007 oraz 2012. Badania zawierają blisko 300 pytań i dostarczają informacji na temat regulacji i nadzoru bankowego w 143 krajach świata. Badania z 2012 r. obejmują okres 2008-2010, a zatem pozwalają porównać stan regulacji i nadzoru bankowego w okresie przedkryzysowym i pokryzysowym w dużej grupie krajów (Čihák i in. 2012). Analizy przeprowadzone przez Bank Światowy charakteryzują się wysokim poziomem staranności wykonania. Ankiety zostały wysłane do najwyższych rangą przedstawicieli w głównej agencji regulacyjnej w każdym kraju. W każdym przypadku, gdy w uzupełnionych przez nadzorców kwestionariuszach ankietowych pojawiały się sprzeczne lub mylące odpowiedzi na pytania, autorzy sprawdzali podwójnie informacje zarówno przez kontakty z organami regulacyjnymi w danym kraju, jak i odnosząc się do innych źródeł (Kara 2016).

Na podstawie serii testów statystycznych wyników badań ankietowych BRSS przeprowadzonych przez Bank Światowy w 2012 r. potwierdzono znaczące różnice w kilku aspektach regulacji i nadzoru pomiędzy krajami, w których wystąpił silny kryzys sektora bankowego w latach 2007-2009, a krajami, w których nie obserwowano zjawisk kryzysowych w sektorze bankowym. Po pierwsze, kraje dotknięte kryzysem sektora bankowego posiadały mniej rygorystyczne definicje kapitału regulacyjnego i niższe rzeczywiste wskaźniki kapitałowe. Po drugie, banki w krajach, gdzie wystąpił kryzys, objęte były mniejszą liczbą ograniczeń w obszarze działalności okołobankowej (ubezpieczenia, inwestycje w nieruchomości). Po trzecie, przepisy dotyczące procedur w zakresie ekspozycji kredytowych z utratą wartości były w tej grupie krajów mniej rygorystyczne. W krajach dotkniętych kryzysem obserwowano ponadto słabsze bodźce dla rynkowego monitorowania ryzyka banków (Čihák i in. 2012).

Na podstawie wyników przedstawionych przez K. Sum (2016, s. 1-40) skonstruowano zagregowany indeks restrykcyjności regulacji. Autorka przypisała punktację do poszczególnych obszarów analiz regulacyjno-nadzorczych zgodnie z metodologią zastosowaną w pracy (Barth, Caprio i Levine 2004, s. 205-248) - wyższe oceny przyporządkowane zostały bardziej rygorystycznym regulacjom w poszczególnych krajach UE. Większość odpowiedzi o charakterze tak/nie uwzględnionych w tych analizach dotyczyło pytań o istnienie określonych przepisów prawnych. Odpowiedziom przypisywano 0 pkt w przypadku liberalnych regulacji i 1 pkt w przypadku surowych przepisów. W przypadku pytań o zakres regulacji (z możliwością wyboru jednej lub kilku opcji ze zbioru alternatyw) przyjęto punktację z przedziału 1-4 pkt, gdzie wyższe wartości wskazują na większą restrykcyjność regulacji. Ocenę regulacji oparto na analizie głównych składowych, a ostateczne wyniki oparte są na pierwszym głównym składniku każdej grupy.

Poziom restrykcyjności regulacji dla sektorów bankowych obliczony na podstawie badań Banku Światowego z 2012 r. w poszczególnych krajach został 


\begin{tabular}{|c|c|c|c|c|c|c|c|c|c|c|c|c|c|c|c|c|c|c|c|c|c|c|}
\hline & 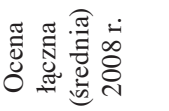 & ले & $\hat{\imath}$ & $\frac{0}{0}$ & $\stackrel{0}{-}$ & $\stackrel{\infty}{0}$ & 8 & $\begin{array}{l}0 \\
0 \\
0 \\
i\end{array}$ & $\begin{array}{l}8 \\
0 \\
0\end{array}$ & $\begin{array}{l}-0 \\
0 \\
1\end{array}$ & $\frac{m}{0}$ & $\begin{array}{l}0 \\
0 \\
0\end{array}$ & $\overrightarrow{\vec{\sigma}_{0}}$ & $\begin{array}{lll}\infty & \\
0 & 0\end{array}$ & & $\frac{m}{0} \stackrel{\infty}{c}$ & $\frac{n}{0}$ & $\begin{array}{l}8 \\
0 \\
0\end{array}$ & 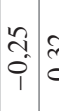 & $\begin{array}{ll}2 & 9 \\
2 & 0 \\
0 & 0\end{array}$ & 8 & $\underset{i}{i}$ \\
\hline & 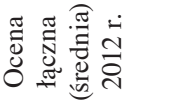 & $\begin{array}{l}8 \\
0 \\
0 \\
1\end{array}$ & $\begin{array}{l}0 \\
0 \\
0 \\
1\end{array}$ & $\begin{array}{c}m \\
m \\
0\end{array}$ & \pm & $\begin{array}{l}0 \\
\hat{1} \\
0 \\
1\end{array}$ & $\begin{array}{l}n \\
n \\
0 \\
1\end{array}$ & $\begin{array}{l}\vec{m} \\
\hat{\varphi} \\
1\end{array}$ & हి. & $\begin{array}{l}\hat{n} \\
0 \\
0 \\
1\end{array}$ & $\begin{array}{l}\hat{8} \\
0 \\
0\end{array}$ & $\stackrel{\partial}{\circ}$ & $\frac{2}{i}$ & $\begin{array}{l}0 \\
0 \\
0\end{array}$ & $\begin{array}{l} \pm \\
0\end{array}$ & 0 & $\frac{0}{0}$ & $\frac{7}{0}$ & \begin{tabular}{lll}
$\vec{N}$ & \multirow{2}{*}{} \\
0 & 0
\end{tabular} & \begin{tabular}{l|l}
\multirow{1}{*}{} & \multirow{2}{*}{} \\
0 & 0
\end{tabular} & $\begin{array}{l}8 \\
0 \\
0 \\
1\end{array}$ & $\stackrel{\infty}{\stackrel{1}{i}}$ \\
\hline & .оozpru & . & $\stackrel{\simeq}{T}$ & ले. & 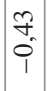 & $\begin{array}{l}\overrightarrow{\hat{n}} \\
\hat{0} \\
1\end{array}$ & . & $\begin{array}{l}\infty \\
\tilde{o}^{\infty} \\
0\end{array}$ & & $\cdot$ & $\begin{array}{l}\vec{m} \\
p_{1}\end{array}$ & $\frac{1}{0}$ & $\begin{array}{l}n \\
n \\
i \\
i\end{array}$ & m. & $\begin{array}{l}8 \\
\vdots \\
0 \\
1\end{array}$ & $\begin{array}{ll}0 & \tilde{7} \\
0 & 1\end{array}$ & $\begin{array}{l}5 \\
0 \\
0\end{array}$ & $\begin{array}{l}n \\
n \\
0\end{array}$ & 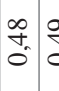 & \begin{tabular}{c|c}
0 \\
\multirow{1}{*}{} \\
0 & 0 \\
0
\end{tabular} & $\begin{array}{l}q \\
\dot{q} \\
0\end{array}$ & . \\
\hline & 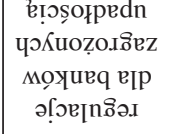 & :ै. & $\begin{array}{l}+ \\
N_{2}^{2} \\
0\end{array}$ & $\begin{array}{c}\infty \\
m_{0}^{\infty} \\
0\end{array}$ & $\mid \begin{array}{l}n \\
n \\
0 \\
0\end{array}$ & in & \begin{tabular}{l}
$\infty$ \\
\multirow{1}{*}{} \\
0 \\
0
\end{tabular} & $\begin{array}{l}n \\
0 \\
0 \\
1\end{array}$ & $\begin{array}{l}\infty \\
0 \\
0 \\
0\end{array}$ & 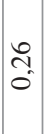 & $\begin{array}{l}n \\
\hat{0} \\
0\end{array}$ & $\because$ & $\begin{array}{l}0 \\
\vdots \\
0 \\
0\end{array}$ & $\begin{array}{l}\text { సे } \\
0\end{array}$ & \begin{tabular}{l}
0 \\
\hdashline \\
0
\end{tabular} & 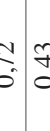 & 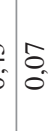 & $\vec{F}$ & $\stackrel{0}{0}$ & \begin{tabular}{l|l}
0 & \multicolumn{1}{c}{} \\
0 & 0
\end{tabular} & in & $\underset{i}{i}$ \\
\hline & 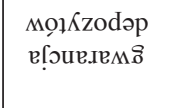 & 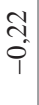 & $\begin{array}{l}1 \\
1 \\
0 \\
1\end{array}$ & $\begin{array}{l}0 \\
0 \\
0\end{array}$ & $\begin{array}{c}0 \\
0 \\
0\end{array}$ & $\begin{array}{c}\hat{f} \\
\dot{0} \\
i\end{array}$ & to & $\begin{array}{l}0 \\
n \\
0 \\
i \\
1\end{array}$ & $\begin{array}{l}\overrightarrow{0} \\
0\end{array}$ & $\begin{array}{l}\hat{E} \\
\hat{0}\end{array}$ & $\stackrel{m}{0}$ & \begin{tabular}{l} 
I \\
\multirow{2}{1}{} \\
1
\end{tabular} & $\begin{array}{l}\infty \\
n \\
0 \\
0\end{array}$ & . & $\begin{array}{lll}a & \\
\vdots & 0 \\
1 & 0\end{array}$ & \begin{tabular}{c|c}
0 \\
0 \\
0.7
\end{tabular} & है & $\overrightarrow{\tilde{n}}$ & 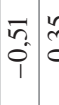 & 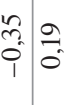 & $=$ & . \\
\hline$\stackrel{\vec{A}}{\mathrm{I}}$ & 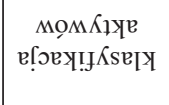 & $\begin{array}{l}8 \\
0 \\
0 \\
1\end{array}$ & & $\stackrel{0}{ \pm}$ & $\begin{array}{l}0 \\
0 \\
0 \\
0 \\
1\end{array}$ & & $\begin{array}{l}\text { t } \\
0 \\
0 \\
1\end{array}$ & $\begin{array}{l}0 \\
0 \\
0 \\
1\end{array}$ & $\begin{array}{l}0 \\
0 \\
0 \\
1\end{array}$ & $\stackrel{\infty}{0}$ & $\begin{array}{l}\text { Oे } \\
0 \\
0\end{array}$ & $\begin{array}{l}0 \\
0 \\
0\end{array}$ & . & $\begin{array}{l}m \\
0 \\
0\end{array}$ & $\begin{array}{ll}0 & \\
0 \\
0 \\
1\end{array}$ & 00 & $\int_{0}^{\infty}$ & $\vec{i}$ & $\begin{array}{l}\text { î. } \\
\text { ñ. } \\
0\end{array}$ & $\cdot \mid \begin{array}{l}0 \\
0 \\
0 \\
i\end{array}$ & $\begin{array}{l}n \\
0 \\
0 \\
1\end{array}$ & \\
\hline 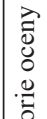 & 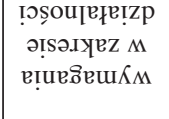 & $\dot{\partial}$ & $\dot{J}_{0}^{+}$ & $\begin{array}{c}1 \\
0 \\
1\end{array}$ & $\begin{array}{l}0 \\
0 \\
0\end{array}$ & $\begin{array}{l}1 \\
\tilde{0} \\
0\end{array}$ & $\begin{array}{l}\text { iे } \\
\text { i }\end{array}$ & $\begin{array}{l}3 \\
0 \\
1\end{array}$ & $\overrightarrow{0}$ & $\hat{\hat{o}}$ & $\begin{array}{l}\infty \\
0 \\
0\end{array}$ & $\begin{array}{l}\tilde{1} \\
\tilde{0}\end{array}$ & $\frac{0}{0}$ & \begin{tabular}{l}
\multirow{y}{f}{} \\
$\stackrel{0}{0}$ \\
1
\end{tabular} & 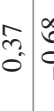 & 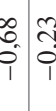 & $\begin{array}{l}\infty \\
0 \\
0 \\
1\end{array}$ & $\mid \begin{array}{c}T \\
\dot{f} \\
0 \\
1\end{array}$ & in & $\begin{array}{ll}0 & 0 \\
0 & 0\end{array}$ & 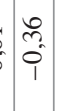 & ñ \\
\hline 气 & 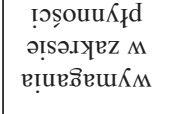 & $\begin{array}{l}\infty \\
0 \\
0 \\
i\end{array}$ & $\begin{array}{l}\infty \\
1 \\
0 \\
0\end{array}$ & $\begin{array}{l}n \\
n \\
0\end{array}$ & $\begin{array}{c}0 \\
0 \\
0 \\
1\end{array}$ & 苟 & à & $\begin{array}{l}n \\
\hat{0} \\
i\end{array}$ & $\begin{array}{l}I_{+} \\
0 \\
0\end{array}$ & $\frac{1}{0}$ & $\begin{array}{l}0 \\
n \\
0 \\
i\end{array}$ & $\begin{array}{l}m \\
0 \\
0\end{array}$ & $\begin{array}{l}n \\
\\
\end{array}$ & $\begin{array}{l}0 \\
\dot{0} \\
0\end{array}$ & ले है & 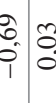 & 8 & $\frac{\infty}{0}$ & fy & $\begin{array}{lll}n & \hat{n} \\
2 & 0 \\
0 & 0\end{array}$ & $\frac{m}{9}$ & O. \\
\hline & 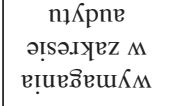 & $\begin{array}{l}\infty \\
0 \\
0 \\
1\end{array}$ & $\begin{array}{l}n \\
2 \\
0 \\
1 \\
1\end{array}$ & $\mid \begin{array}{l}\infty \\
n \\
0 \\
1 \\
1\end{array}$ & $\hat{\imath}$ & $\begin{array}{l}0 \\
0 \\
0 \\
1\end{array}$ & $\begin{array}{l}n \\
\hat{n} \\
\hat{1} \\
1\end{array}$ & 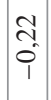 & $\vec{\sigma}$ & $\begin{array}{l}\tilde{N} \\
\text { i }\end{array}$ & $\frac{2}{0}$ & $\begin{array}{l}\text { f. } \\
\text { ó } \\
1\end{array}$ & $\begin{array}{l}\hat{i} \\
\hat{1}\end{array}$ & $\begin{array}{l}\overrightarrow{0} \\
0\end{array}$ & ले. & $\begin{array}{ll}1 & n \\
0 & 0 \\
0 & 0 \\
1 & 0 \\
0\end{array}$ & is & ले & 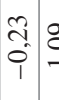 & 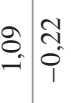 & $\begin{array}{l}q \\
f \\
i \\
i\end{array}$ & $\frac{1}{t}$ \\
\hline & 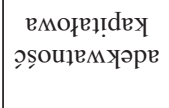 & $\begin{array}{l}\bar{r} \\
\hat{0} \\
1\end{array}$ & $\begin{array}{l}8 \\
0 \\
0 \\
1 \\
1\end{array}$ & $\begin{array}{l}\vec{g} \\
i\end{array}$ & $\begin{array}{c}\infty \\
1 \\
1 \\
0 \\
1\end{array}$ & $\begin{array}{l}m \\
0 \\
1\end{array}$ & in & $\begin{array}{l}0 \\
0 \\
i \\
1\end{array}$ & $\begin{array}{l}\infty \\
\stackrel{1}{0}\end{array}$ & $\begin{array}{l} \pm \\
0 \\
\end{array}$ & $\begin{array}{l}m \\
m_{1}^{2}\end{array}$ & $\overrightarrow{0}$ & $\begin{array}{l}\vec{m} \\
\text { ?. } \\
1\end{array}$ & $\begin{array}{l}\hat{\imath} \\
\hat{0} \\
1\end{array}$ & 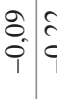 & $\begin{array}{ll}1 & n \\
0 & 0 \\
1 & 0\end{array}$ & ? & 辛 & $\overrightarrow{0}$ & 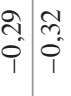 & $\frac{2}{0}$ & $\begin{array}{l}n \\
1 \\
0 \\
1\end{array}$ \\
\hline & 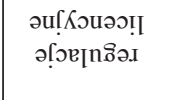 & $\frac{m}{0}$ & $\dot{0}_{0}$ & $\begin{array}{l}\hat{0} \\
\hat{\infty} \\
i\end{array}$ & $\begin{array}{c}\hat{2} \\
\hat{0}\end{array}$ & $\stackrel{\substack{T \\
T}}{T}$ & $\because$ & $\begin{array}{l}\hat{2} \\
0 \\
i\end{array}$ & $\overrightarrow{\vec{\sigma}_{0}}$ & $\hat{i}$ & $\begin{array}{l}\tilde{y} \\
\tilde{0}\end{array}$ & $\begin{array}{l}\infty \\
\vdots \\
0 \\
0\end{array}$ & $\begin{array}{c}\hat{\text { â }} \\
\text { o. }\end{array}$ & $\begin{array}{l}n \\
\\
0 \\
0\end{array}$ & $\begin{array}{l}n \\
\text { nิ } \\
0\end{array}$ & 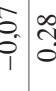 & 0 & $\mid \vec{m}$ & $\stackrel{f}{f}$ & \begin{tabular}{l|l} 
\pm & $\bar{n}$ \\
0 & 0
\end{tabular} & $\vec{F}$ & $\frac{ \pm}{1}$ \\
\hline & 苟 & 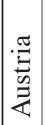 & 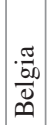 & 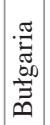 & 峞 & 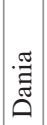 & 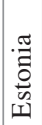 & 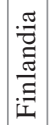 & 吾 & 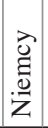 & 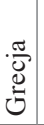 & $\begin{array}{c}\overrightarrow{2} \\
\vec{b} \\
3^{\infty}\end{array}$ & 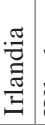 & $\begin{array}{l}\frac{\vec{c}}{0} \\
\text { D } \\
\text { i }\end{array}$ & $\stackrel{\frac{\pi}{3}}{3}$ & 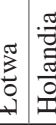 & $\frac{\pi}{\frac{\pi}{0}}$ & 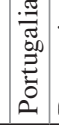 & 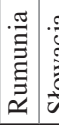 & 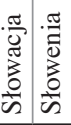 & 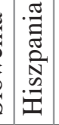 & 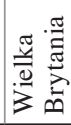 \\
\hline
\end{tabular}


przedstawiony w tabeli 3. Wykazano istotne zróżnicowanie intensywności regulacji w badanych krajach. W krajach Europy Środkowo-Wschodniej w większości przypadków wskazuje się na silną restrykcyjność wymogów regulacyjnych (Sum 2015, s. 207-236).

Zmienną przybliżającą intensywność globalnych zmian regulacyjnych, wykorzystaną w modelu w dalszej części pracy, jest także miara oparta na przeciętnej rocznej liczbie zmian, które muszą implementować banki. W latach 2004-2007 liczba zmian regulacyjnych w obszarze bankowości była relatywnie stabilna i wynosiła ok. 150. Od 2008 r. obserwowano trwały, silny trend wzrostowy (z wyjątkiem 2012 r.) w zakresie wdrażanych przez banki zmian regulacyjnych, co doprowadziło do podwojenia liczby implementowanych przez instytucje kredytowe regulacji (rys. 2).

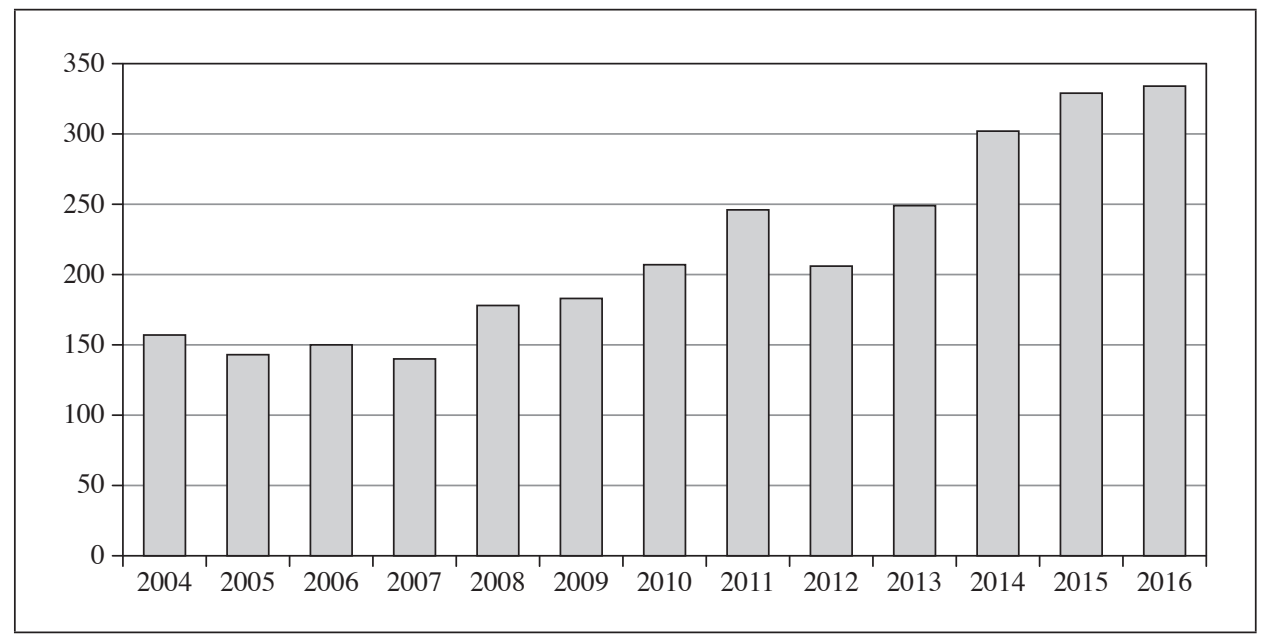

Rys. 2. Wartość indeksu globalnych zmian regulacyjnych w obszarze bankowości w latach 2004-2016

Źródło: https://cdn2.hubspot.net/hubfs/40143/BCI_Report_Q1_2017_.pdf?t=1495061834808 (data dostępu: 9.06.2017).

\section{Wyniki badań}

Wyniki badań determinant stabilności banków spółdzielczych w Unii Europejskiej przedstawiono w tabeli 4 (dla $T C R$ i $T 1 R$ ) oraz w tabeli 5 (dla Z-score i $M L P$ Score). We wszystkich analizowanych modelach charakterystyki dotyczące regulacji sektora bankowego okazały się istotnymi czynnikami kształtującymi stabilność banków spółdzielczych w Unii Europejskiej, przy czym kierunek 
i siła wpływu były zróżnicowane. W przypadku ocen stabilności opartych na miernikach adekwatności kapitałowej wzrost liczby regulacji warunkował wzrost wartości wskaźników $T C R$ i $T 1 R$ dla całej grupy badawczej, w szczególności w krajach o znaczącym udziale banków spółdzielczych w sektorze bankowym.

Tabela 4. Wyniki badań panelowych determinant banków spółdzielczych w Unii Europejskiej - zmienne objaśniane $T C R$ oraz $T 1 R$

\begin{tabular}{|c|c|c|c|c|c|c|}
\hline \multirow{2}{*}{ Zmienna } & \multicolumn{3}{|c|}{$T C R$} & \multicolumn{3}{|c|}{$T 1 R$} \\
\hline & ogółem & grupa 1 & grupa 2 & ogółem & grupa 1 & grupa 2 \\
\hline $\operatorname{STAB}(-1)$ & $\begin{array}{c}0,754 * * * \\
(0,08)\end{array}$ & $\begin{array}{c}0,758 * * * \\
(0,094)\end{array}$ & $\begin{array}{c}0,632 * * * \\
(0,198)\end{array}$ & $\begin{array}{c}0,761 * * * \\
(0,132)\end{array}$ & $\begin{array}{c}0,735 * * * \\
(0,132)\end{array}$ & $\begin{array}{c}0,690 * * * \\
(0,203)\end{array}$ \\
\hline Const & $\begin{array}{c}10,044 * * * \\
(3,542)\end{array}$ & $\begin{array}{c}9,921^{* *} \\
(4,137)\end{array}$ & $\begin{array}{c}0,032 \\
(0,321)\end{array}$ & $\begin{array}{l}9,788^{*} \\
(5,623)\end{array}$ & $\begin{array}{c}11,169^{*} \\
(5,717)\end{array}$ & $\begin{array}{c}0,368 \\
(0,406)\end{array}$ \\
\hline$P K B$ & $\begin{array}{c}0,021 \\
(0,017)\end{array}$ & $\begin{array}{c}0,020 \\
(0,018)\end{array}$ & $\begin{array}{c}0,127 \\
(0,149)\end{array}$ & $\begin{array}{c}0,011 \\
(0,016)\end{array}$ & $\begin{array}{c}0,011 \\
(0,017)\end{array}$ & $\begin{array}{c}-0,266^{*} \\
(0,155)\end{array}$ \\
\hline$C P I$ & $\begin{array}{c}-0,236 * * * \\
(0,052)\end{array}$ & $\begin{array}{c}-0,24 * * * \\
(0,054)\end{array}$ & $\begin{array}{l}-0,192 \\
(0,194)\end{array}$ & $\begin{array}{c}-0,318 * * * \\
(0,045)\end{array}$ & $\begin{array}{c}-0,309 * * * \\
(0,046)\end{array}$ & $\begin{array}{l}-0,269 \\
(0,192)\end{array}$ \\
\hline$S P$ & $\begin{array}{l}-0,015 \\
(0,074)\end{array}$ & $\begin{array}{c}0,003 \\
(0,077)\end{array}$ & $\begin{array}{l}-0,315 \\
(0,302)\end{array}$ & $\begin{array}{c}0,061 \\
(0,065)\end{array}$ & $\begin{array}{c}0,057 \\
(0,065)\end{array}$ & $\begin{array}{l}0,556^{*} \\
(0,299)\end{array}$ \\
\hline$H H I$ & $\begin{array}{c}1,944 \\
(2,254)\end{array}$ & $\begin{array}{l}1,647 \\
(2,22)\end{array}$ & $\begin{array}{c}-82,547 \\
(130,917)\end{array}$ & $\begin{array}{c}4,147 \\
(3,908)\end{array}$ & $\begin{array}{l}4,966 \\
(3,94)\end{array}$ & $\begin{array}{c}183,867 \\
(130,545)\end{array}$ \\
\hline$K R \_P K B$ & $\begin{array}{c}0,004 \\
(0,004)\end{array}$ & $\begin{array}{c}0,004 \\
(0,004)\end{array}$ & $\begin{array}{c}0,017 \\
(0,031)\end{array}$ & $\begin{array}{c}0,004 \\
(0,004)\end{array}$ & $\begin{array}{c}0,003 \\
(0,004)\end{array}$ & $\begin{array}{l}0,000 \\
(0,03)\end{array}$ \\
\hline$L_{-} A K$ & $\begin{array}{c}-0,249 * * \\
(0,097)\end{array}$ & $\begin{array}{c}-0,237 * * \\
(0,112)\end{array}$ & $\begin{array}{l}-1,259 \\
(1,794)\end{array}$ & $\begin{array}{c}-0,289 * \\
(0,171)\end{array}$ & $\begin{array}{c}-0,322 * \\
(0,173)\end{array}$ & $\begin{array}{c}-3,027^{*} \\
(1,548)\end{array}$ \\
\hline NIM & $\begin{array}{c}0,069 \\
(0,153)\end{array}$ & $\begin{array}{c}0,033 \\
(0,161)\end{array}$ & $\begin{array}{l}-0,031 \\
(0,482)\end{array}$ & $\begin{array}{c}0,079 \\
(0,218)\end{array}$ & $\begin{array}{c}0,099 \\
(0,209)\end{array}$ & $\begin{array}{c}-0,849 * \\
(0,461)\end{array}$ \\
\hline$R O E$ & $\begin{array}{c}0,044 * * * \\
(0,011)\end{array}$ & $\begin{array}{c}0,045^{* * *} \\
(0,011)\end{array}$ & $\begin{array}{c}0,087 * * \\
(0,037)\end{array}$ & $\begin{array}{c}0,044 * * * \\
(0,014)\end{array}$ & $\begin{array}{c}0,040 \text { *** } \\
(0,014)\end{array}$ & $\begin{array}{c}0,153 * * * \\
(0,038)\end{array}$ \\
\hline$C_{-} I$ & $\begin{array}{l}-0,01^{*} \\
(0,006)\end{array}$ & $\begin{array}{l}-0,009 \\
(0,006)\end{array}$ & $\begin{array}{l}-0,024 \\
(0,017)\end{array}$ & $\begin{array}{c}-0,015^{* *} \\
(0,007)\end{array}$ & $\begin{array}{c}-0,015^{* *} \\
(0,007)\end{array}$ & $\begin{array}{c}-0,009 \\
(0,017)\end{array}$ \\
\hline$A P \_D K$ & $\begin{array}{l}-0,001 \\
(0,006)\end{array}$ & $\begin{array}{l}-0,004 \\
(0,006)\end{array}$ & $\begin{array}{c}0,013 \\
(0,012)\end{array}$ & $\begin{array}{l}-0,006 \\
(0,006)\end{array}$ & $\begin{array}{l}-0,009 \\
(0,006)\end{array}$ & $\begin{array}{c}0,014 \\
(0,009)\end{array}$ \\
\hline$N P L$ & $\begin{array}{l}-0,015 \\
(0,015)\end{array}$ & $\begin{array}{l}-0,015 \\
(0,015)\end{array}$ & $\begin{array}{c}-0,112^{*} \\
(0,059)\end{array}$ & $\begin{array}{l}-0,026 \\
(0,018)\end{array}$ & $\begin{array}{c}-0,031 \\
(0,02)\end{array}$ & $\begin{array}{l}0,008 \\
(0,05)\end{array}$ \\
\hline$K_{-} A$ & $\begin{array}{c}-0,050 * * * \\
(0,014)\end{array}$ & $\begin{array}{c}-0,051 * * * \\
(0,017)\end{array}$ & $\begin{array}{c}-0,079 * * \\
(0,039)\end{array}$ & $\begin{array}{c}-0,053 * * \\
(0,023)\end{array}$ & $\begin{array}{c}-0,058 * * \\
(0,023)\end{array}$ & $\begin{array}{l}-0,031 \\
(0,036)\end{array}$ \\
\hline$W O \_W N O$ & $\begin{array}{c}0,000 \\
(0,000)\end{array}$ & $\begin{array}{c}0,000 \\
(0,000)\end{array}$ & $\begin{array}{c}-0,001 * * \\
(0,000)\end{array}$ & $\begin{array}{c}0,000 \\
(0,001)\end{array}$ & $\begin{array}{c}0,000 \\
(0,001)\end{array}$ & $\begin{array}{c}-0,002 * * * \\
(0,001)\end{array}$ \\
\hline$D E P_{-} W Z$ & $\begin{array}{l}0,004^{*} \\
(0,002)\end{array}$ & $\begin{array}{l}0,004^{*} \\
(0,002)\end{array}$ & $\begin{array}{c}0,004 \\
(0,004)\end{array}$ & $\begin{array}{c}0,002 \\
(0,002)\end{array}$ & $\begin{array}{c}0,002 \\
(0,002)\end{array}$ & $\begin{array}{c}0,009 * * * \\
(0,004)\end{array}$ \\
\hline
\end{tabular}


cd. tabeli 4

\begin{tabular}{|c|c|c|c|c|c|c|}
\hline \multirow{2}{*}{ Zmienna } & \multicolumn{3}{|c|}{$T C R$} & \multicolumn{3}{c|}{$T 1 R$} \\
\cline { 2 - 7 } & ogółem & grupa 1 & grupa 2 & ogółem & grupa 1 & grupa 2 \\
\hline RESTR_REG & 0,337 & 0,252 & $4,298 * *$ & 1,887 & 2,285 & $48,510 * *$ \\
$(0,408)$ & $(0,43)$ & $(2,064)$ & $(1,472)$ & $(1,454)$ & $(23,715)$ \\
\hline REG_GLOB & $0,005 * * *$ & $0,004 * * *$ & 0,008 & $0,008 * * *$ & $0,009 * * *$ & 0,006 \\
$(0,001)$ & $(0,001)$ & $(0,006)$ & $(0,001)$ & $(0,001)$ & $(0,006)$ \\
\hline Test AR(1) & $-4,919 * * *$ & $-4,554 * *$ & $-1,969 * *$ & $-3,472 * * *$ & $-3,373 * * *$ & $-1,574$ \\
\hline Test AR(2) & $-0,928$ & $-0,905$ & $-0,996$ & $-0,997$ & $-0,999$ & $-0,613$ \\
\hline $\begin{array}{c}\text { Statystyka } \\
\text { Hansena } \\
p \text {-value }\end{array}$ & 0,235 & 0,319 & 0,271 & 0,426 & 0,411 & 0,438 \\
\hline $\begin{array}{c}\text { Statystyka } \\
\text { Walda }\end{array}$ & $339,130 * * *$ & $311,520 * * *$ & $220,431 * * *$ & $278,580 * * *$ & $222,000 * * *$ & $590,290 * * *$ \\
\hline $\begin{array}{c}\text { Liczba } \\
\text { obserwacji }\end{array}$ & 4954 & 4522 & 301 & 4253 & 3931 & 216 \\
\hline
\end{tabular}

Uwaga: *** istotność na poziomie $1 \%, * *$ istotność na poziomie $5 \%, *$ istotność na poziomie $10 \%$. W nawiasach podano wartości błędów standardowych.

Źródło: opracowanie własne.

Tabela 5. Wyniki badania panelowego determinant banków spółdzielczych w Unii Europejskiej - zmienna objaśniana Z-score oraz MLPS

\begin{tabular}{|c|c|c|c|c|c|c|}
\hline \multirow{2}{*}{ Zmienna } & \multicolumn{3}{|c|}{ Z-score } & \multicolumn{3}{c|}{ MLP Score } \\
\cline { 2 - 7 } & ogółem & grupa 1 & grupa 2 & ogółem & grupa 1 & grupa 2 \\
\hline \multirow{2}{*}{ STAB $(-1)$} & $1,099 * * *$ & $1,101 * * *$ & $0,711^{* * *}$ & $0,524 * * *$ & $0,523 * * *$ & $0,525 * * *$ \\
& $(0,006)$ & $(0,006)$ & $(0,047)$ & $(0,028)$ & $(0,029)$ & $(0,150)$ \\
\hline \multirow{2}{*}{ const } & $-2,679$ & $-2,466$ & $2,542 * * *$ & $-9,989 * * *$ & $-10,003 * * *$ & 0,953 \\
& $(2,618)$ & $(2,72)$ & $(0,96)$ & $(2,399)$ & $(2,429)$ & $(0,731)$ \\
\hline PKB & $0,133 * *$ & $0,108 * *$ & $-0,098$ & $0,199 * * *$ & $0,213 * * *$ & 0,355 \\
& $(0,053)$ & $(0,055)$ & $(0,477)$ & $(0,052)$ & $(0,053)$ & $(0,596)$ \\
\hline \multirow{2}{*}{$C P I$} & $-0,061$ & $-0,053$ & $-1,199 * *$ & 0,007 & 0,009 & $-0,888^{* *}$ \\
& $(0,219)$ & $(0,229)$ & $(0,543)$ & $(0,122)$ & $(0,124)$ & $(0,414)$ \\
\hline \multirow{2}{*}{$S P$} & $-0,438$ & $-0,451$ & 1,008 & $0,507 * * *$ & $0,521 * * *$ & $0,519 * * *$ \\
& $(0,422)$ & $(0,445)$ & $(0,741)$ & $(0,149)$ & $(0,151)$ & $(0,134)$ \\
\hline \multirow{2}{*}{$H H I$} & $-8,537$ & $-6,048$ & $-15,903$ & 9,578 & 9,826 & $-349,618$ \\
& $(5,86)$ & $(5,752)$ & $(380,369)$ & $(7,203)$ & $(7,146)$ & $(433,298)$ \\
\hline KR_PKB & 0,007 & 0,002 & $-0,016$ & $-0,047 * * *$ & $-0,045^{* * *}$ & $-0,043$ \\
& $(0,027)$ & $(0,029)$ & $(0,084)$ & $(0,011)$ & $(0,011)$ & $(0,098)$ \\
\hline \multirow{2}{*}{$L_{-} A K$} & 0,169 & 0,125 & $-4,067$ & $0,917 * * *$ & $0,896 * * *$ & $-7,290 *$ \\
& $(0,162)$ & $(0,171)$ & $(4,547)$ & $(0,117)$ & $(0,12)$ & $(3,962)$ \\
\hline
\end{tabular}


cd. tabeli 5

\begin{tabular}{|c|c|c|c|c|c|c|}
\hline \multirow{2}{*}{ Zmienna } & \multicolumn{3}{|c|}{$Z$-score } & \multicolumn{3}{|c|}{ MLP Score } \\
\hline & ogółem & grupa 1 & grupa 2 & ogółem & grupa 1 & grupa 2 \\
\hline NIM & $\begin{array}{c}0,872 \\
(0,607)\end{array}$ & $\begin{array}{c}0,973 \\
(0,636)\end{array}$ & $\begin{array}{c}2,796 \\
(1,989)\end{array}$ & $\begin{array}{c}2,081 * * * \\
(0,242)\end{array}$ & $\begin{array}{c}2,014 * * * \\
(0,249)\end{array}$ & $\begin{array}{c}6,671 * * * \\
(1,614)\end{array}$ \\
\hline$R O E$ & $\begin{array}{c}0,083 * * \\
(0,036)\end{array}$ & $\begin{array}{c}0,080^{* *} \\
(0,036)\end{array}$ & $\begin{array}{c}0,253 * * * \\
(0,060)\end{array}$ & $x$ & $\times$ & $x$ \\
\hline$C_{-} I$ & $\begin{array}{l}-0,023 \\
(0,018)\end{array}$ & $\begin{array}{l}-0,024 \\
(0,019)\end{array}$ & $\begin{array}{c}0,001 \\
(0,073)\end{array}$ & $x$ & $x$ & $x$ \\
\hline$A P \_D K$ & $\begin{array}{l}-0,018 \\
(0,013)\end{array}$ & $\begin{array}{l}-0,019 \\
(0,014)\end{array}$ & $\begin{array}{c}0,070 * * \\
(0,032)\end{array}$ & $\begin{array}{c}-0,068^{* * *} \\
(0,010)\end{array}$ & $\begin{array}{c}-0,066^{* * *} \\
(0,010)\end{array}$ & $\begin{array}{c}-0,120 * * * \\
(0,046)\end{array}$ \\
\hline$N P L$ & $\begin{array}{c}0,148 * * * \\
(0,029)\end{array}$ & $\begin{array}{c}0,152 * * * \\
(0,03)\end{array}$ & $\begin{array}{c}0,130 \\
(0,166)\end{array}$ & $x$ & $x$ & $x$ \\
\hline$K_{-} A$ & $\begin{array}{l}-0,001 \\
(0,019)\end{array}$ & $\begin{array}{c}0,000 \\
(0,021)\end{array}$ & $\begin{array}{c}0,414 * * * \\
(0,147)\end{array}$ & $\times$ & $x$ & $\times$ \\
\hline$W O \_W N O$ & $\begin{array}{c}0,000 \\
(0,000)\end{array}$ & $\begin{array}{c}0,000 \\
(0,000)\end{array}$ & $\begin{array}{l}-0,001 \\
(0,001)\end{array}$ & $\begin{array}{c}0,000 \\
(0,000)\end{array}$ & $\begin{array}{c}0,000 \\
(0,000)\end{array}$ & $\begin{array}{c}-0,003^{* *} \\
(0,001)\end{array}$ \\
\hline$D E P \_W Z$ & $\begin{array}{l}0,008^{*} \\
(0,004)\end{array}$ & $\begin{array}{c}0,009 * * \\
(0,004)\end{array}$ & $\begin{array}{c}0,000 \\
(0,012)\end{array}$ & $\begin{array}{c}0,003 \\
(0,005)\end{array}$ & $\begin{array}{c}0,003 \\
(0,005)\end{array}$ & $\begin{array}{c}0,024 \\
(0,016)\end{array}$ \\
\hline$R E S T R \_R E G$ & $\begin{array}{c}-3,570 * * * \\
(1,107) \\
\end{array}$ & $\begin{array}{c}-3,243 * * * \\
(1,158) \\
\end{array}$ & $\begin{array}{c}65,911 * * * \\
(11,537)\end{array}$ & $\begin{array}{c}-2,387 * * * \\
(0,733)\end{array}$ & $\begin{array}{c}-2,386 * * * \\
(0,761) \\
\end{array}$ & $\begin{array}{l}-149,164 \\
(107,789)\end{array}$ \\
\hline$R E G \_G L O B$ & $\begin{array}{c}-0,026^{* * *} \\
(0,005)\end{array}$ & $\begin{array}{c}-0,023^{* * *} \\
(0,006)\end{array}$ & $\begin{array}{c}-0,025 \\
(0,02)\end{array}$ & $\begin{array}{l}-0,002 \\
(0,003)\end{array}$ & $\begin{array}{l}-0,002 \\
(0,003)\end{array}$ & $\begin{array}{l}-0,024 \\
(0,018)\end{array}$ \\
\hline $\begin{array}{l}\text { Test } A R(1) \\
\text { Test } A R(2)\end{array}$ & $\begin{array}{c}0,945 \\
-5,154 * * *\end{array}$ & $\begin{array}{c}0,931 \\
-5,174 * * *\end{array}$ & $\begin{array}{l}-1,597 \\
-0,196\end{array}$ & $\begin{array}{c}-15,100 \text { *** } \\
-0,594\end{array}$ & $\begin{array}{c}-14,876 \text { *** } \\
-0,596\end{array}$ & $\begin{array}{c}-3,014 * * * \\
-0,487\end{array}$ \\
\hline $\begin{array}{c}\text { Statystyka } \\
\text { Hansena } \\
\text { p-value }\end{array}$ & 0,000 & 0,000 & 0,000 & 0,189 & 0,206 & 0,195 \\
\hline $\begin{array}{c}\text { Statystyka } \\
\text { Walda }\end{array}$ & $186,450 * * *$ & $159,440 * * *$ & $951,302 * * *$ & $256,140 * * *$ & $235,470 * * *$ & $301,623 * * *$ \\
\hline $\begin{array}{c}\text { Liczba } \\
\text { obserwacji }\end{array}$ & 5450 & 4976 & 332 & 4264 & 3957 & 201 \\
\hline
\end{tabular}

Uwaga: *** istotność na poziomie $1 \%$, ** istotność na poziomie $5 \%$, * istotność na poziomie $10 \%$. W nawiasach podano wartości błędów standardowych.

Źródło: opracowanie własne.

W przypadku banków działających w krajach z nieznaczną rolą bankowości spółdzielczej istotną determinantą stabilności finansowej okazała się restrykcyjność regulacji sieci bezpieczeństwa finansowego kraju. Zależność ta ma charakter dodatni, a wartość współczynnika kierunkowego zmiennej jest wysoka. W krajach o wyższych wymogach regulacyjnych (w obszarze regulacji licencyjnych, audytu, płynności, działalności bankowej, klasyfikacji aktywów, gwarancji depozytów, 
zagrożenia upadłością, adekwatności kapitałowej i nadzoru) banki spółdzielcze charakteryzowały się zatem lepszą oceną stabilności mierzonej współczynnikami wypłacalności.

Odmienne wnioski dotyczą oceny stabilności z wykorzystaniem indeksu MLPS. W analizowanej próbie banków wykazano istotny negatywny wpływ intensywności regulacji bankowych w kraju na stabilność banków spółdzielczych, w szczególności w krajach o większym znaczeniu bankowości spółdzielczej. Wykorzystanie miernika opartego na szerszej definicji stabilności finansowej wskazuje zatem, że długookresowe zwiększanie restrykcyjności regulacji przez podmioty sieci bezpieczeństwa finansowego pomimo zwiększania bazy kapitałowej banków doprowadza do pogorszenia wielokryterialnej stabilności finansowej.

W modelu ze zmienną objaśnianą Z-score wartość testu autokorelacji Arellano-Bonda dla pierwszych różnic $A R(1)$ okazała się dodatnia i nieistotna statystycznie, co uniemożliwia przeprowadzenie prawidłowego wnioskowania statystycznego (model ten nie będzie poddawany interpretacji w dalszej części pracy).

Wśród czynników makroekonomicznych wpływających dodatnio na stabilność banków spółdzielczych potwierdzono istotność dynamiki PKB kraju dla banków spółdzielczych ogółem w przypadku wskaźników MLPS. Ujemny wpływ wskaźnika inflacji $H I C P$ na wartości $T C R$ i $T 1 R$ potwierdzono dla grupy wszystkich banków oraz dla banków z grupy 1, natomiast dla banków z grupy 2 taki kierunek wpływu został potwierdzony w przypadku wskaźnika MLPS. Dodatnia zależność między poziomem rynkowych stóp procentowych a stabilnością banków spółdzielczych (wskaźnik MLPS) została potwierdzona w przypadku banków spółdzielczych działających we wszystkich sektorach bankowych, co potwierdza wskazywaną w literaturze znaczącą wrażliwość banków spółdzielczych na funkcjonowanie w warunkach historycznie niskich stóp procentowych.

Warte uwagi są także wnioski dotyczące wpływu rozmiarów sektora bankowego kraju na stabilność banków spółdzielczych. W przypadku MLPS zależność ma charakter ujemny (mocno rozbudowane sektory bankowe charakteryzują się gorszą oceną stabilności mierzoną tym indeksem).

Wśród czynników mikroekonomicznych (charakterystyk banków spółdzielczych) szczególną uwagę zwrócić należy na kwestię zależności między wielkością banku a jego stabilnością finansową. Wyniki nie pozwoliły na jednoznaczną ocenę tego oddziaływania. W przypadku miar stabilności opartych na adekwatności kapitałowej potwierdzono ujemny wpływ wielkości banku na wartości wskaźników $T C R$ oraz $T 1 R$ dla całej próby. W przypadku oparcia oceny stabilności finansowej banku na wskaźniku $M L P S$ zależność miała odwrotny kierunek (z wyjątkiem sektorów o niewielkim udziale bankowości spółdzielczej). Wyniki te $\mathrm{z}$ jednej strony mogą utwierdzić regulatorów w przekonaniu, że duże banki spółdzielcze opierają swoją działalność na kapitałach regulacyjnych o niższej wartości 
i aktywach oraz zobowiązaniach pozabilansowych o wyższym poziomie ryzyka, z drugiej strony przy ocenie długookresowej stabilności opartej też na miarach rentowności pojawiające się korzyści skali powodują mniejszą zmienność osiąganych wyników finansowych, zapewniając w długim okresie źródła powiększania kapitałów własnych.

Istotne znaczenie dla poziomu wskaźników $T C R$ oraz $T 1 R$ miały ponadto w całej grupie badawczej m.in. rentowność banku (mierzona $R O E$ ) - dodatni kierunek zależności, oraz efektywność kosztowa $(C / I)$ - oddziałująca negatywnie. Wyniki te dowodzą, że uzyskiwanie wyższej rentowności nie musi odbywać się kosztem pogarszania jakości kapitałów, ale przeciwnie - lepsze wyniki finansowe stanowią istotne narzędzie tworzenia kapitału własnego (co w przypadku banków spółdzielczych jest szczególnie wyraźne z uwagi na mniejsze oczekiwania w zakresie wypłaty dywidend).

Wykazano ponadto ujemny istotny statystycznie wpływ udziału kredytów dla sektora niefinansowego w aktywach na wartość TCR i $T 1 R$ banków spółdzielczych. Jedną z przyczyn mogą być często zdecydowanie wyższe wagi ryzyka kredytowego dla tego typu ekspozycji w stosunku do innych kategorii aktywów. Potwierdzone zostają tym samym obawy nadzorców, że nowe pokryzysowe regulacje nadzorcze w zakresie adekwatności kapitałowej mogą zniechęcać banki do kredytowania sektora niefinansowego.

W przypadku wskaźnika MLPS potwierdzono ponadto istotny ujemny wpływ poziomu płynności banku (mierzonego relacją aktywów płynnych do depozytów krótkoterminowych) na wartość wskaźników $T C R$ i $T 1 R$. Kosztem wzrostu poziomu płynności może być zmniejszenie dochodów wynikające m.in. z utraty korzyści w postaci wyższych odsetek.

\section{Wnioski}

Przeprowadzone badania dotyczące wpływu restrykcyjności regulacji nadzorczych na stabilność finansową banków spółdzielczych w krajach UE stanowią ważne źródło informacji dla podmiotów sieci bezpieczeństwa finansowego w poszczególnych krajach Unii Europejskiej. Charakterystyki dotyczące regulacji sektora bankowego okazały się istotnymi czynnikami kształtującymi stabilność banków spółdzielczych w Unii Europejskiej, przy czym kierunek i siła wpływu były zróżnicowane w zależności od wyboru zmiennej charakteryzującej stabilność finansową. W przypadku ocen stabilności opartych na miernikach adekwatności kapitałowej wzrost liczby regulacji warunkował wzrost wartości wskaźników TCR i $T 1 R$ dla całej grupy badawczej, w szczególności w krajach o znaczącym udziale banków spółdzielczych w sektorze bankowym. 
Odmienne wnioski dotyczą oceny stabilności z wykorzystaniem indeksu $M L P S$. W analizowanej próbie banków wykazano istotny negatywny wpływ intensywności regulacji bankowych w kraju na stabilność banków spółdzielczych, w szczególności w krajach o większym znaczeniu bankowości spółdzielczej. Wykorzystanie miernika opartego na szerszej definicji stabilności finansowej wskazuje zatem, że długookresowe zwiększanie restrykcyjności regulacji przez podmioty sieci bezpieczeństwa finansowego pomimo zwiększania bazy kapitałowej banków doprowadza do pogorszenia wielokryterialnej oceny stabilności finansowej.

\section{Literatura}

Alińska A. (2012), Rola i pozycja sieci bezpieczeństwa finansowego w utrzymaniu stabilności systemu finansowego (w:) Polityka monetarna i fiskalna a stabilność sektora finansowego, red. A. Alińska, CeDeWu, Warszawa.

Baltagi B.H. (2013), Econometric Analysis of Panel Data, Wiley, Chichester.

Barth J.R., Caprio J.G., Levine R. (2004), Bank Regulation and Supervision: What Works Best?, ,Journal of Financial Intermediation”, vol. 13, nr 2,. https://doi.org/10.1016/ j.ji.2003.06.002.

Cooperative Banks, Credit Unions and the Financial Crisis (2009), Prepared for the United Nations Expert Group Meeting on Cooperatives, World Council of Credit Unions, April 28-30, New York.

Čihák M., Demirgüç-Kunt A., Martínez Pería M.S., Mohseni-Cheraghlou A. (2012), Bank Regulation and Supervision around the World, „Policy Research Working Paper”, nr 6286.

Dam K. (2010), The Subprime Crisis and Financial Regulation: International and Comparative Perspectives, ,Chicago Journal of International Law”, vol. 10, $\mathrm{nr}$ 2, https://doi. org/10.2139/ssrn.1579048.

Dańska-Borsiak B. (2011), Dynamiczne modele panelowe w badaniach ekonomicznych, Wydawnictwo Uniwersytetu Łódzkiego, Łódź.

Diaconu I.R., Oanea D.C. (2015), Determinants of Bank's Stability. Evidence from CreditCoop, ,Procedia Economics and Finance”, vol. 32, https://doi.org/10.1016/s22125671(15)01422-7.

Ferri G. (2012), Credit Cooperatives: Challenges and Opportunities in the New Global Scenario, „European Research Institute on Cooperative and Social Enterprises Working Paper", nr 31.

Fiordelisi F., Mare D.S. (2014), Competition and Financial Stability in European Cooperative Banks, ,Journal of International Money and Finance”, vol. 45, https://doi.org/ 10.1016/j.jimonfin.2014.02.008.

Gradoń W. (2014), Metody oceny stabilności systemu bankowego w Polsce, „Studia Ekonomiczne. Zeszyty Naukowe Uniwersytetu Ekonomicznego w Katowicach", nr 186.

Hesse H., Čihák M. (2007), Cooperative Banks and Financial Stability, „IMF Working Paper", WP/07/02. 
Kara G.I. (2016), Bank Capital Regulations around the World: What Explains the Differences?, Finance and Economics Discussion Series 2016-057, Board of Governors of the Federal Reserve System, Washington, https://doi.org/10.17016/feds.2016.057.

Kasiewicz S., Kurkliński L. (2014), Zasada proporcjonalności w świetle wyników badania ankietowego banków (w:) Rynek finansowy jako mechanizm alokacji zasobów $w$ gospodarce, red. J. Czekaj, E. Miklaszewska, W. Sułkowska, Wydawnictwo Uniwersytetu Ekonomicznego w Krakowie, Kraków.

Kozak S. (2010), Stabilność i dochodowość banków spółdzielczych w Polsce w czasie kryzysu rynków finansowych, „Zeszyty Naukowe Szkoły Głównej Gospodarstwa Wiejskiego w Warszawie. Polityki Europejskie, Finanse i Marketing”, nr 4.

Kozłowski Ł. (2015), Wpływ konkurencji ze strony spółdzielczych kas oszczędnościowo-kredytowych na stabilność banków spółdzielczych: analiza rynków lokalnych, „Bezpieczny Bank”, nr 4(61).

Księżopolski R. (2013)., Zmiany w zarzq̨dzaniu działalnościq detalicznq banków w Polsce w warunkach kryzysu finansowego, CeDeWu, Warszawa.

Maciejewski K. (2014), Tsunami nad gospodarkq, „Miesięcznik Finansowy Bank”, nr 7-8(257).

Masiukiewicz P., Morawska S. (2015), Regulacje rynku finansowego. Aspekty prakseologiczne, ,Zarządzanie i Finanse”, nr 3(1).

Merrouche O., Nier E. (2010), What Caused the Global Financial Crisis? Evidence on the Drivers of Financial Imbalances 1999-2007, „IMF Working Paper”, WP/10/265.

Miklaszewska E. (2011a), The Consequences of Post-crisis Regulatory Architecture for the Banks in Central Eastern Europe, „Prace Naukowe Uniwersytetu Ekonomicznego we Wrocławiu", nr 201.

Miklaszewska E. (2011b), Model biznesowy i wielkość banku a jego bezpieczeństwo analiza empiryczna, „Prace Naukowe Uniwersytetu Ekonomicznego we Wrocławiu”, nr 124.

Miklaszewska E., Kil K. (2016), The Impact of 2007-2009 Crisis on the Assessment of Bank Performance: The Evidence from CEE-11 Countries, ,Transformations in Business and Economics", vol. 15, nr 2A(38A).

Nowacka A., Szewczyk-Jarocka M. (2015), Lokalny charakter działalności banków spółdzielczych, ,Studia Ekonomiczne. Zeszyty Naukowe Uniwersytetu Ekonomicznego w Katowicach", nr 250.

Rogowski W., Mesjasz C. (2012), Definicje stabilności finansowej (w:) Nadzór korporacyjny a stabilność sektora finansowego, red. P. Urbanek, Wydawnictwo Uniwersytetu Łódzkiego, Łódź.

Sum K. (2015), Banking Regulation and Bank Performance in the EU - What Should Be the Scope of the Regulatory Reform?, „Bank i Kredyt”, $\mathrm{nr} 46(3)$.

Sum K. (2016), Banking Regulation and Bank Lending in the EU. Opportunities and Threats, Springer International Publishing, Basel.

Szambelańczyk J. (2010), Stabilność systemu bankowego a paradygmat bankowości, „Finanse”, nr 1(2). 


\section{The Impact of Restrictiveness of Supervisory Regulations on the Stability of Cooperative Banks in the EU}

(Abstract)

The aim of the study presented in this paper was to identify the determinants of the financial stability of cooperative banks in the European Union in the years 2008-2015. It emphasizes the impact of restrictive regulatory actions on the financial stability of cooperative banks in EU countries. The article reviews the determinants of cooperative bank stability and presents the results of in-depth interviews regarding factors influencing that stability, recognized by bank management or from a safety net point of view. A panel survey, which encompassed 1753 cooperative banks in the EU, has shown that higher capital adequacy ratios of co-operative banks are observed in countries with higher levels of regulatory rigor. On the other hand, the MLPS index confirmed that inflated regulation has a negative effect on the stability of cooperative banks. The use of a broader definition of financial stability suggests that increased restrictiveness of bank regulation implemented by the safety net worsens the multi-criteria financial stability assessment of cooperative banks, despite the increase in the banks' capital base.

Keywords: cooperative banks, financial stability, bank regulation, EU countries. 